\title{
ACCURACY AND EFFICIENCY EVALUATION OF POINT-CENTERED QUARTER METHOD VARIATIONS FOR VEGETATION SAMPLING IN AN ARAUCARIA FOREST ${ }^{1}$
}

\author{
Graziele Hernandes Volpato ${ }^{2}$, Sebastião Venâncio Martins ${ }^{3}$, Joema Carvalho ${ }^{4}$ e Luiz dos Anjos ${ }^{5}$
}

\begin{abstract}
In order to verify Point-Centered Quarter Method (PCQM) accuracy and efficiency, using different numbers of individuals by per sampled area, in 28 quarter points in an Araucaria forest, southern Paraná, Brazil. Three variations of the PCQM were used for comparison associated to the number of sampled individual trees: standard PCQM (SD-PCQM), with four sampled individuals by point (one in each quarter), second measured (VAR1-PCQM), with eight sampled individuals by point (two in each quarter), and third measuring (VAR2-PCQM), with 16 sampled individuals by points (four in each quarter). Thirty-one species of trees were recorded by the SD-PCQM method, 48 by VAR1-PCQM and 60 by VAR2-PCQM. The level of exhaustiveness of the vegetation census and diversity index showed an increasing number of individuals considered by quadrant, indicating that VAR2-PCQM was the most accurate and efficient method when compared with VAR1-PCQM and SD-PCQM.
\end{abstract}

Keywords: Sampling methods, Phytosociology and Mixed Ombrophylous Forest.

\section{AVALIAÇÃO DA EFICIÊNCIA E PRECISÃO DE VARIAÇÕES DO MÉTODO QUADRANTE CENTRADO EM UM PONTO PARA O LEVANTAMENTO DE VEGETAÇÃO EM UMA FLORESTA DE ARAUCÁRIA}

\begin{abstract}
RESUMO - O objetivo deste estudo foi verificar a precisão e a eficiência do método Quadrante Centrado em um Ponto (PCQM), usando diferentes números de indivíduos por amostra, em 28 unidades amostrais em uma área de Floresta Ombrófila Mista no sul do Paraná, Brasil. Foram comparadas três variações do método com relação ao número de indivíduos amostrados: primeira variação (SD-PCQM), amostragem com quatro indivíduos por ponto (um por quadrante), segunda variação (VAR1-PCQM), amostragem com oito indivíduos por ponto (dois em cada quadrante), e terceira variação (VAR2-PCQM), amostragem com 16 indivíduos por ponto (quatro indivíduos em cada quadrante). Foram registradas 31 espécies pelo SD-PCQM, 48 pelo VAR1-PCQM e 60 espécies pelo VAR2-PCQM. O nível de eficiência da amostragem da vegetação e o índice de diversidade apresentaram um acréscimo de acordo com o número de indivíduos por quadrante, incluídos na amostra, indicando que o VAR2-PCQM foi o mais preciso e eficiente método quando comparado com VAR1-PCQM e SD-PCQM.
\end{abstract}

Palavras-chave: Método de amostragem, Fitossociologia e Floresta Ombrófila Mista.

\section{INTRODUCTION}

Phytosociological and floristic studies are fundamental to determine the forest composition and structure, both horizontally and vertically. A wide variety of methods have been used to study forest structure parameters such as population density, basal area, and biomass (MOSCOVICH et al., 1999; DURIGAN, 2003). These methods can be classified in two broad categories: plot-based and plot-less. Plot-based methods begin with one or more plots (e.g., quadrants) of known areas in which the characteristics of interest are measured

\footnotetext{
${ }^{1}$ Recebido em 23.01.2009 e aceito para publicação em 02.03.2010.

${ }^{2}$ Programa de Pós-Graduação em Ciência Florestal na Universidade Federal de Viçosa, Brasil. E-mail: <gravolpato@yahoo.com.br>.

${ }^{3}$ Laboratório de Restauração Florestal, Universidade Federal de Viçosa, UFV, Brasil. E-mail: <venancio@ufv.br>.

${ }^{4}$ Mater Natura - Instituto de estudos Ambientais. Curitiba, Brasil. E-mail: <joemacarvalho@gmail.com>.

${ }^{5}$ Departamento de Biologia Animal e Vegetal da Universidade Estadual de Londrina, Brasil. E-mail: <llanjos@sercomtel.com.br>.
} 
for each single plant. The plot-less methods involve measuring distances in a random sample of trees, typically along one transect. The Point-Centered Quarter Method (PCQM) is one such plot-less method (COTTAM and CURTIS, 1956; MARTINS, 1991).

In PCQM a point is defined as a sampling unit and the area around this point is split into four $90^{\circ}$ quarters (quadrants), and the nearest tree is sampled in each quarter (COTTAM and CURTIS, 1956). In this method, the probability of individual selection sampled in each point quarter is proportional to its distance from the center of the unit.

Since the introduction of PCQM in Brazil, by Fernando Roberto Martins in the late 70's, this method has been often used to sample plant communities, particularly forests (SILVA and MARCONI, 1990; DURIGAN, 2003; SILVA et al., 2003; DORNELES and WAECHTER, 2004; KOREZA et al., 2006; SOARES et al., 2006; BRITO et al. 2007; MOREIRA et al. 2007; RUSCHEL et al. 2009). However, the current method used has some slight differences from the original description by Cottam and Curtis (1956) and Martins (1991). The main advantages of using PCQM are its practical and fast use besides requiring fewer workers and less pieces of equipment, when compared to the quadrate plots method (COTTAM and CURTIS, 1956; GIBBS et al., 1980; MARTINS, 1991; SPARKS et al., 2002).

Despite these advantages, Moscovich et al. (1999) and Durigan (2003) point out some problems in the PCQM, mainly when one considers its small individual sample. Furthermore, in tropical forests the application of the conventional sampling protocol by PCQM is not adequate, leading to some adaptations. They occur because this method was developed for sampling in temperate forests, when the forest structure and composition is simpler. Dahdouh-Guebas and Koedam (2006) proposed variations to adequate PCQM for mangroves field, where multi-stem trees are present and no trees can be sampled in a quarter. However, there is little information on assessing the PCQM in tropical forests, which presents higher tree diversity and structure complexity (MOSCOVICH et al., 1999). The objectives of this study were to evaluate and compare the vegetation sampling accuracy and efficiency for PCQM, varying standard individuals per point quarter in an Araucaria Forest remnant.

\section{Material and Methods}

The study was carried out at Irati National Forest (25 $27^{\prime} \mathrm{S}$ and $50^{\circ} 35^{\prime} \mathrm{W}$ and an altitude of $885 \mathrm{~m}$ ). The vegetation of the National Forest, according to the Castella and Britez (2004), has an optimum preservation condition of Araucaria Forest (Mixed Ombrophylous Forest). In the study area, the vegetation data were collected along one transect by sampling at $50 \mathrm{~m}$ by PCQM. Each point was divided into four quadrants (or quarters) as described by Cottam and Curtis (1956) and Martins (1991). The orientation of the quadrants was at right angles of the transect direction. During fieldwork, in each of the quadrants, trees were measured individually to extract all data, described as follows:

The first measuring represented the standard PCQM description (SD-PCQM) (COTTTAN and CURTIS, 1956; MARTINS, 1991), in which we recorded in each quarter the tree nearest to the square point with a diameter greater than or equal to $16.5 \mathrm{~cm}$ at breast height (DBH) - taller than $1.30 \mathrm{~m}$ from the ground. In a second measuring (VAR1-PCQM), in each quarter we tallied the nearest tree to the square point with a diameter greater than $16.5 \mathrm{~cm} \mathrm{DHB}$ and the nearest tree to the square point with a diameter lower than $16.5 \mathrm{~cm}$ DHB, resulting in a total of eight individual trees by point sample. Finally, in a third measuring (VAR2-PCQM), in each quarter we recorded the two nearest trees to the square point with a diameter greater than $16.5 \mathrm{~cm}$ DHB and the two nearest trees to the square point with a diameter lesser than $16.5 \mathrm{~cm}$ DHB, giving a total of sixteen individual trees by point sample. The $\mathrm{DBH}$ inclusion criterion was defined with the objective of including trees belonging to the canopy (adult trees) and belonging to the understory (young trees vegetation layer).

The phytosociological parameters (density, frequency and dominance relative) were calculated and then the Importance Value (IV), Equitability (J) and Shannon Diversity (H') were determined. The chi-square test $\left(\chi^{2}\right)$ was used to determine the difference in the number of species between the tested methods. Spearman's rank correlation $\left(r_{s}\right)$ was used to measure 
the relation between the community structures recorded by the three methods. We used the first-order jackknife method to estimate the total species richness (COLWELL, 2000). Sampling exhaustiveness of each variation of the method was calculated by dividing the observed total richness by the estimated total richness. The Jaccard index was used to compare the results obtained by the three tested method variations with similar results obtained by Silva and Marconi (1990), Koreza et al. (2006) and Schaaf et al. (2006).

\section{Results and Discussion}

As expected, we found a wide variation within number of species among the three variations of the method. The number of species sampled by VAR2-PCQM was higher than the two other variations of the method $\left(\chi_{0.0001 ; 2}^{2}=40.2\right)$. About 31 species belonging to 18 families by SD-PCQM, 48 species belonging to 23 families by VAR1-PCQM, and 60 species belonging to 25 families by VAR2-PCQM, were recorded (Tables 1 and 2). Considering the three variation methods, an increase of species can be observed of 35.4\% between SD-PCQM and VAR1-PCQM, 48.3\% between SD-PCQM and VAR2-PCQM, and 20\% between VAR1-PCQM and VAR2-PCQM. The results indicated that the level of exhaustiveness of plant census and diversity index improved with the increasing number of individuals considered by the quadrant (Table 1).

According to VAR2-PCQM, the families Lauraceae (ten species), Myrtaceae (eight species) and Rosaceae (six species) were the most numerous, representing
$40 \%$ of the species. By VAR1-PCQM and SD-PCQM, Lauraceae presented the highest number of species (eight species in both variations of the methods), representing $16.66 \%$ and $25.8 \%$, respectively (Table 2). Several studies in the Araucaria Forest show similar results for trees families, with different methods and inclusion criteria (OLIVEIRA and ROTTA, 1982; SILVA and MARCONI, 1990; NEGRELLE and SILVA, 1992; SILVA et al., 1997; RONDON NETO et al., 2002a and 2002b; FORMENTO et al., 2004; NARVÁEZ et al,. 2005; KOREZA et al., 2006; SCHAAF et al., 2006; SONEGO et al. 2007).

PCQM is more advantageous than the Quadrant Plots Method for adult trees (canopy trees), since it is faster and costs are reduced. The disadvantages of this method for forest understory can be minimized by complementing the sampling with the young tree vegetation layer (COTTAM and CURTIS, 1956; GIBBS et al., 1980; CAVASSAN et al., 1984; SPARKS et al., 2002, DAHDOUH-GUEBAS and KOEDAM, 2006). The evaluation of the three variations of the method showed that recording tree individuals with different inclusion criteria can lead to the identification and characterization of the distinct structures of the Araucaria forest (Table 2). In their study on the Araucaria forest, Koreza et al. (2006) classified as satisfactory the use of two inclusion criteria by tree vegetation samples using PCQM. Our results indicate that the absence of inclusion criteria by SD-PCQM represented a decrease of $15.4 \%$ of canopy tree species when compared to VAR2-PCQM, suggesting a relationship between the inclusion criteria and the vegetation structure of the forest.

Table 1 - Species richness observed and estimated, number of families, level of species exhaustiveness and diversity index sampled in the three point-centered quarter method evaluated in Araucaria forest, southern Brazil. SD-PCQM (standard PCQM, with four sampled individuals by point), VAR1-PCQM (second measured of PCQM, with eight sampled individuals by point), VAR2-PCQM (third measuring of PCQM, with 16 sampled individuals by points).

Tabela 1 - Riqueza de espécies observadas e estimadas, número de famílias, grau de eficiência de estimativa de espécies e índice de diversidade amostrado nos três métodos de ponto quadrante avaliados em uma floresta de Araucária, sul do Brasil. SD-PCQM (primeira variação do PCQM, amostragem com quatro indivíduos por ponto), VAR1PCQM (segunda variação do PCQM, amostragem com oito indivíduos por ponto) e VAR2-PCQM (terceira variação do PCQM, amostragem com 16 indivíduos por ponto).

\begin{tabular}{cccccc}
\hline $\begin{array}{c}\text { Variation on } \\
\text { Method evaluated }\end{array}$ & Total Richness & Families & $\begin{array}{c}\text { Jackknife } \\
\text { estimation } \\
\text { of total richness }\end{array}$ & $\begin{array}{c}\text { Species } \\
\text { exhaustiveness (\%) }\end{array}$ & $\begin{array}{c}\text { Shannon } \\
\text { Diversity (H’) }\end{array}$ \\
\hline SD-PCQM & 31 & 18 & 48.36 & 64.10 & 3.02 \\
VAR1-PCQM & 48 & 23 & 69.21 & 69.35 & 0.88 \\
VAR2-PCQM & 60 & 25 & 84.11 & 71.33 & 0.83 \\
\hline
\end{tabular}

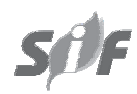

Revista Árvore, Viçosa-MG, v.34, n.3, p.513-520, 2010 
Table 2 - Taxonomical list of species sampled in the study area by different Point-Centered Quarter Methods evaluated in the Araucaria forest, southern Brazil. Canopy: tree height above: $16.5 \mathrm{~cm} \mathrm{DBH}$; and Understory: tree height below $16.5 \mathrm{~cm}$ DBH and higher than $1.30 \mathrm{~m}$ tall above the floor. Method abbreviations are shown in Table 1.

Tabela 2 - Lista taxonômica das espécies amostradas utilizando variações do método por pontos quadrantes em uma floresta de Araucária no sul do Brasil. Dossel: árvores maiores que 16,5 cm DHB; e Sub-bosque: árvores com DHB inferior a 16, $5 \mathrm{~cm}$ e maiores de 1, $30 \mathrm{~m}$ de altura. Abreviações dos métodos são indicadas na Tabela 1.

\begin{tabular}{|c|c|c|c|c|c|c|}
\hline \multirow[t]{2}{*}{ Species } & \multirow[t]{2}{*}{ Families } & \multicolumn{3}{|c|}{ Canopy } & \multicolumn{2}{|c|}{ Understory } \\
\hline & & $\begin{array}{c}\text { SD- } \\
\text { PCQM }\end{array}$ & $\begin{array}{l}\text { VAR1- } \\
\text { PCQM }\end{array}$ & $\begin{array}{l}\text { VAR2- } \\
\text { PCQM }\end{array}$ & $\begin{array}{l}\text { VAR1- } \\
\text { PCQM }\end{array}$ & $\begin{array}{l}\text { VAR2- } \\
\text { PCQM }\end{array}$ \\
\hline Rollinia sylvatica (St. Hil.) Mart. & Annonaceae & & & & $\mathrm{x}$ & $\mathrm{x}$ \\
\hline Ilex dumosa Reissek & Aquifoliaceae & $\mathrm{x}$ & $\mathrm{x}$ & $\mathrm{x}$ & $\mathrm{x}$ & $\mathrm{x}$ \\
\hline Ilex paraguariensis A. St-Hill. & Aquifoliaceae & $\mathrm{x}$ & $\mathrm{x}$ & $\mathrm{x}$ & $\mathrm{x}$ & $\mathrm{x}$ \\
\hline Ilex theezans Mart. & Aquifoliaceae & & & $\mathrm{x}$ & $\mathrm{x}$ & $\mathrm{x}$ \\
\hline $\begin{array}{l}\text { Schefflera morototoni (Aubl.) Maguire, Steyerm. } \\
\text { \& Frodin }\end{array}$ & Araliaceae & $\mathrm{x}$ & $\mathrm{x}$ & $\mathrm{x}$ & & \\
\hline Araucaria angustifolia (Bertol.) Kuntze & Araucariaceae & $\mathrm{x}$ & $\mathrm{x}$ & $\mathrm{x}$ & & \\
\hline Syagrus romanzzoffianum (Cham.) Glassman & Arecaceae & $\mathrm{x}$ & $\mathrm{x}$ & $\mathrm{x}$ & & $\mathrm{x}$ \\
\hline Piptocarpha angustifolia Dusén ex Malme & Asteraceae & $\mathrm{x}$ & $\mathrm{x}$ & $\mathrm{x}$ & & \\
\hline Jacaranda puberula Cham. & Bigboniaceae & $\mathrm{x}$ & $\mathrm{x}$ & $\mathrm{x}$ & & \\
\hline Tabebuia sp. & Bigboniaceae & & & $\mathrm{x}$ & $\mathrm{x}$ & $\mathrm{x}$ \\
\hline Capsicodendro dinisii (Schwacke) & Canellaceae & & & & $\mathrm{x}$ & $\mathrm{x}$ \\
\hline Clethra uleana Sleumer & Clethraceae & $\mathrm{x}$ & $\mathrm{x}$ & $\mathrm{x}$ & & \\
\hline Dickisonia sellowiana Hook. & Dicksoniaceae & $\mathrm{x}$ & $\mathrm{x}$ & $\mathrm{x}$ & $\mathrm{x}$ & $\mathrm{x}$ \\
\hline Sloanea guianensis (Autbl.) Benth. & Elaeocarpaceae & & & & $\mathrm{x}$ & $\mathrm{x}$ \\
\hline Sloanea monosperma Vell. & Elaeocarpaceae & $\mathrm{x}$ & $\mathrm{x}$ & $\mathrm{x}$ & & \\
\hline Dalbergia frutescens (Vell.) Britton & Fabaceae & & & & $\mathrm{x}$ & $\mathrm{x}$ \\
\hline Inga sp. & Fabaceae & & & & & $\mathrm{x}$ \\
\hline Machaerium sp. & Fabaceae & $\mathrm{x}$ & $\mathrm{x}$ & $\mathrm{x}$ & & \\
\hline Parapiptademia rigida (Benth) Brenan & Fabaceae & & & & $\mathrm{x}$ & $\mathrm{x}$ \\
\hline Casearia sylvestris Sw. & Flacourtiaceae & & & $\mathrm{x}$ & & \\
\hline Vitex megapotamica (Spreng.) Moldenke & Lamiaceae & $\mathrm{x}$ & $\mathrm{x}$ & $\mathrm{x}$ & $\mathrm{x}$ & $\mathrm{x}$ \\
\hline Cinnamomum sp. & Lauraceae & & & $\mathrm{x}$ & & \\
\hline Nectandra megapotamica (Spreng.) Mez & Lauraceae & $\mathrm{x}$ & $\mathrm{x}$ & $\mathrm{x}$ & $\mathrm{x}$ & $\mathrm{x}$ \\
\hline Nectandra lanceolata Ness & Lauraceae & $\mathrm{x}$ & $\mathrm{x}$ & $\mathrm{x}$ & $\mathrm{x}$ & $\mathrm{x}$ \\
\hline Nectandra sp. & Lauraceae & & & $\mathrm{x}$ & & \\
\hline Ocotea elegans Mez & Lauraceae & $\mathrm{x}$ & $\mathrm{x}$ & $\mathrm{x}$ & & \\
\hline Ocotea odorifera (Vellozo) Rohwer & Lauraceae & $\mathrm{x}$ & $\mathrm{x}$ & $\mathrm{x}$ & & \\
\hline Ocotea porosa (Ness \& C. Mart.) & Lauraceae & $\mathrm{x}$ & $\mathrm{x}$ & $\mathrm{x}$ & & \\
\hline Ocotea pretiosa Benth. \& Hook. & Lauraceae & $\mathrm{x}$ & $\mathrm{x}$ & $\mathrm{x}$ & $\mathrm{x}$ & $\mathrm{x}$ \\
\hline Ocotea puberula (Rich.) Ness & Lauraceae & $\mathrm{x}$ & $\mathrm{x}$ & $\mathrm{x}$ & & $\mathrm{x}$ \\
\hline Ocotea pulchella (Nees et Mart. Ex Nees) Nees & Lauraceae & $\mathrm{x}$ & $\mathrm{x}$ & $\mathrm{x}$ & & $\mathrm{x}$ \\
\hline Miconia petropolitana Cogn. & Melastomatacea & & & & $\mathrm{x}$ & $\mathrm{x}$ \\
\hline Cabralea canjarana (Vell.) Mart. & Meliaceae & $\mathrm{x}$ & $\mathrm{x}$ & $\mathrm{x}$ & & $\mathrm{x}$ \\
\hline Cedrela fissilis Vell. & Meliaceae & & & $\mathrm{x}$ & $\mathrm{x}$ & $\mathrm{x}$ \\
\hline Trichillia catigua A. Juss. & Meliaceae & $\mathrm{x}$ & $\mathrm{x}$ & $\mathrm{x}$ & & $\mathrm{x}$ \\
\hline Mollinedia clavigera Tul. & Monimiaceae & & & & $\mathrm{x}$ & $\mathrm{x}$ \\
\hline Soroceae bonplandii (Baillon) W. Burger & Moraceae & $\mathrm{x}$ & $\mathrm{x}$ & $\mathrm{x}$ & & \\
\hline Myrsine umbelata (Mart.) Mez & Myrsinaceae & $\mathrm{x}$ & $\mathrm{x}$ & $\mathrm{x}$ & $\mathrm{x}$ & $\mathrm{x}$ \\
\hline Myrsine ferruginea (Ruiz \& Pav.) Spreng. & Myrsinaceae & & & $\mathrm{x}$ & & \\
\hline Blepharocalyx salicifolius (Kunth) O. Berg & Myrtaceae & & & & $\mathrm{x}$ & $\mathrm{x}$ \\
\hline Campomanesia xanthocarpa (Kunth) O. Berg & Myrtaceae & $\mathrm{x}$ & $\mathrm{x}$ & $\mathrm{x}$ & & $\mathrm{x}$ \\
\hline Eugenia involucrata DC. & Myrtaceae & & & & & $\mathrm{x}$ \\
\hline Gomidesia sp. & Myrtaceae & & & & $\mathrm{x}$ & $\mathrm{x}$ \\
\hline
\end{tabular}


Tabela 2 - Cont.

Table 2 - Cont.

\begin{tabular}{|c|c|c|c|c|c|c|}
\hline Myrcearia tenella Berg. & Myrtaceae & & & & & $\mathrm{x}$ \\
\hline Myrceugenia myrcioides (Cambess.) O. Berg & Myrtaceae & $\mathrm{x}$ & $\mathrm{x}$ & $\mathrm{x}$ & $\mathrm{x}$ & $\mathrm{x}$ \\
\hline Myrcia ferruginea (Poir.) DC. & Myrtaceae & & & & $\mathrm{x}$ & $\mathrm{x}$ \\
\hline Myrcia rostrata DC. & Myrtaceae & & & & $\mathrm{x}$ & $\mathrm{x}$ \\
\hline Piper sp. & Piperaceae & & & & & $\mathrm{x}$ \\
\hline Prunus brasiliensis (Cham. \& Schltdl.) D. Dietr. & Rosaceae & $\mathrm{x}$ & $\mathrm{x}$ & $\mathrm{x}$ & $\mathrm{x}$ & $\mathrm{x}$ \\
\hline Coussarea contracta (Walpert) Müll. Arg. & Rosaceae & $\mathrm{x}$ & $\mathrm{x}$ & $\mathrm{x}$ & $\mathrm{x}$ & $\mathrm{x}$ \\
\hline Psychotria leiocarpa Cham. Et Schlecht & Rosaceae & & & & & $\mathrm{x}$ \\
\hline Psychotria suterella Müll. Arg. & Rosaceae & & & & $\mathrm{x}$ & $\mathrm{x}$ \\
\hline Psychotria carthagenensis Jacq. & Rosaceae & & & & & $\mathrm{x}$ \\
\hline Rudgea jasminoides (Cham.) Müll. Arg. & Rosaceae & $\mathrm{x}$ & $\mathrm{x}$ & $\mathrm{x}$ & $\mathrm{x}$ & $\mathrm{x}$ \\
\hline $\begin{array}{l}\text { Allophylus edulis (A. St.-Hil., Cambess. \& A. Juss.) } \\
\text { Radlk. }\end{array}$ & Sapindaceae & $\mathrm{x}$ & $\mathrm{x}$ & $\mathrm{x}$ & $\mathrm{x}$ & $\mathrm{x}$ \\
\hline Cupania vernalis Cambess. & Sapindaceae & & & $\mathrm{x}$ & & $\mathrm{x}$ \\
\hline Diatenopteryx sorbifolia Radlk. & Sapindaceae & & & & $\mathrm{x}$ & $\mathrm{x}$ \\
\hline Matayba elaeagnoides Radlk. & Sapindaceae & $\mathrm{x}$ & $\mathrm{x}$ & $\mathrm{x}$ & & $\mathrm{x}$ \\
\hline Cestrum intermedium Sendtn. & Solanaceae & & & & & $\mathrm{x}$ \\
\hline Solanum swartzianum Roem. \& Schult. & Solanaceae & & & & $\mathrm{x}$ & $\mathrm{x}$ \\
\hline
\end{tabular}

The Jaccard index of similarity also reflected this relationship (Table 3 ). Considering the evaluated variations of the methods in our study, all of them showed higher similarity with the results observed by Schaaf et al. (2006), which used the quadrant method by phytosociological sampling. Koreza et al. (2006) used a method equivalent to the VAR1-PCQM variation, and the similarity index was higher than our results when compared with the VAR2-PCQM variation. The lower similarity index was found between the tested variations of the method and the results by Silva and Marconi (1990), who used original descriptions of Cottam and Curtis (1956). Still, the lower similarity between Koreza et al. (2006), Silva and Marconi (1990) and the tested variations of the method can be credited by the considered inclusion criteria of tree sampling.
Regarding species IV, the Spearman correlation coefficient showed that vegetation structure in the three variation methods had a considerable correlation (SD-CPQM x VAR1-CPQM, $\mathrm{r}_{\mathrm{s} 0.0001}=0.65$; SD-CPQM $\mathrm{x}$ VAR2-CPQM, $\mathrm{r}_{\mathrm{s} 0.0001}=0.81$; VAR1-CPQM x VAR2-CPQM, $\left.r_{s 0.001}=0.77\right)$. However, the relative density, frequency and dominance showed variation in their values among the methods (Figure 1). Amidst species with the highest IV, Araucaria angustifolia showed a dominant presence in the three methods, but only by SD-PCQM this species showed higher relative density (12.9\%). Dickisonia sellowiana had the highest relative density by VAR1-CPQM and VAR2CPQM, with $15.4 \%$ and $15.7 \%$, respectively. In the same way, Coussarea contracta had the highest relative density by VAR1-CPQM and VAR2-CPQM

Table 3 - J accard index of similarity between three Point-Centered Quarter Method (PCQM) evaluated and three phytosociological studies in the Araucaria forest: PCQM with 1 ha and sampling trees taller than $20 \mathrm{~cm}$ DHB (SCHAAF et al., 2006); PCQM and sampling the nearest tree taller than $30 \mathrm{~cm}$ DHB and the nearest tree between 10 and 29 cm DHB, taller than $1.30 \mathrm{~m}$ above the floor (KOREZA et al., 2006); PCQM and sampling the nearest tree higher than $15 \mathrm{~cm}$ DHB (SILVA and MARCONI, 1990). Method abbreviations are shown in Table 1.

Tabela 3 - Índice de similaridade de Jaccard entre as três variações no método por ponto quadrante (PCQM) avaliado e três estudos de fitossociologia em florestas de araucárias. PCQM com 1 ha e amostragem de árvores maiores de $20 \mathrm{~cm}$ DHB (SCHAAF et al., 2006); PCQM e amostragem do indivíduo arbóreo mais próximo ao ponto com DHB maior que $30 \mathrm{~cm}$ e mais outro indivíduo com DHB entre 10 e $29 \mathrm{~cm}$ DHB e com altura superior a 1,30 m (KOREZA et al., 2006); e PCQM e amostragem do indivíduo arbóreo mais próximo ao ponto com DHB maior que $15 \mathrm{~cm}$ (SILVA e MARCONI, 1990). Abreviações dos métodos são indicadas na Tabela 1.

\begin{tabular}{cccc}
\hline Variation in the Method & Schaaf et al. (2006) & Koreza et al. (2006) & Silva and Marconi (1990) \\
\hline SD-PCQM & 0.31 & 0.19 & 0.21 \\
VAR1-PCQM & 0.34 & 0.28 & 0.25 \\
VAR2-PCQM & 0.43 & 0.34 & 0.30 \\
\hline
\end{tabular}



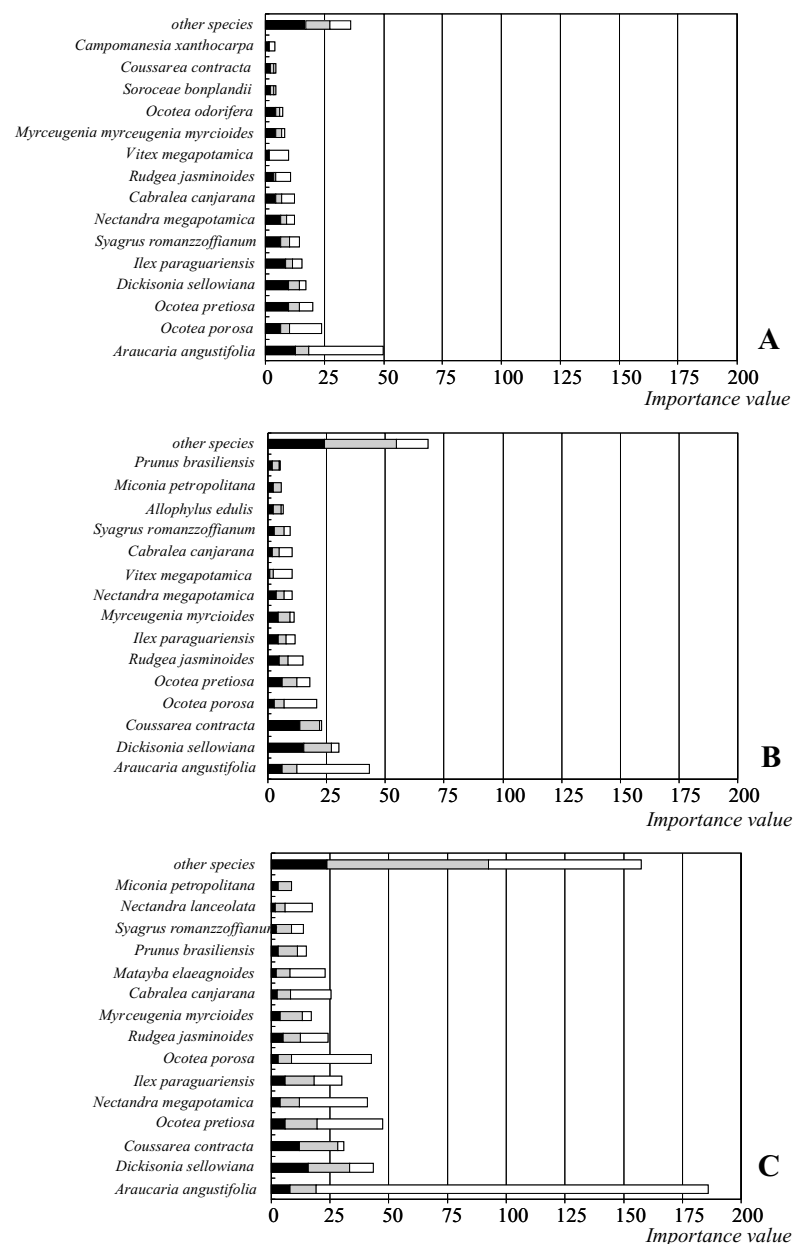

Figure 1-Importance value (IV) with value of Relative Density (black bar), Relative Dominance (gray bar) and Relative Frequency (white bar) for the most important species among the three Point-Centered Quarter Method evaluated (A: SD-PCQM; B: VAR1-PCQM; C: VAR2-PCQM). Method abbreviations are shown in Table 1.

Figura 1 - Valor de Importância (VI) com os valores da densidade relativa (barra preta), dominância relativa (barra cinza) e frequência relativa (barra branca) para as espécies mais importantes amostradas pelos três métodos de ponto quadrante avaliados (A: SD-PCQM; B: VAR1-PCQM; e C: VAR2-PCQM). Abreviações dos métodos são indicadas na Tabela 1.

(13.8\% and $12.1 \%$, respectively), when by SD-PCQM it showed as only $2.1 \%$. Therefore, vegetation data recorded by SD-CPQM can lead to an underestimation and poor characterization in phytosociological surveys of forests (SPARKS et al., 2002; GORENSTEIN et al., 2007; BRITO et al., 2007).

Revista Árvore, Viçosa-MG, v.34, n.3, p.513-520, 2010
The results indicated that VAR2-PCQM variation was the most accurate and efficient variation of the method when compared to VAR1-PCQM and SD-PCQM variations for phytosociological sampling in the Araucaria forest. The adoption of inclusion criteria in PCQM resulted in a better characterization of the forest understory, increased its adequacy and allowed a better utilization of the sampled area. In this way, the proposed adaptation can increase the efficiency of the PCQM as proposed by Cottam and Curtis (1956) and Martins (1991), resulting in an improved phytosociological and floristic characterization of a sampled area.

\section{ACKNOWLEDGEMENTS}

The financial support for this study was provided by CNPq, Brazil (Conselho Nacional de Desenvolvimento Científico e Tecnológico) through the Mata Atlântica Program (690146/01-9) and DTI grant to author J. Carvalho. The first author acknowledges the grant from CAPES. The Instituto Brasileiro do Meio Ambiente e dos Recursos Naturais Renováveis (IBAMA) gave permission to research the studied area.

\section{REFERENCES}

BRITO, A. et al. Comparação entre os métodos de quadrantes e prodon para análises florística, fitossociológica e volumétrica. Cerne, v.13, n.4, p.399-405, 2007.

CAstella, P. P.; BRITEZ, R. M. A floresta com araucária no Paraná: conservação e diagnóstico dos remanescentes

florestais. Brasília: Fundação de Pesquisas Florestais do Paraná/PROBIO. Ministério do Meio Ambiente, 2004.

CAVASSAN, O.; CÉSAR, O.; MARTINS, F. R. Fitossociologia da vegetação arbórea da Reserva Estadual de Bauru, Estado de São Paulo. Revista Brasileira de Botânica, v.7, n.1, p.91-106, 1984.

COLWELL, R. K. EstimateS: statistical estimation of species richness and shared species from samples. 2000.Version 6.0. User's Guide and application published at: < http:// viceroy.eeb.uconn.edu/estimates>.

COTTAM, G.; CURTIS, J. T. The use of distance measures in phytosociological sampling. Ecology, v. 37, n. 3, p. 451-460, 1956. 
DAHDOUH-GUEBAS, F.; KOEDAM, N. Empirical estimate of the reliability of the use of the PointCentred Quarter Method (PCQM): Solutions to ambiguous field situations and description of the PCQM protocol. Forest Ecology

Management, v.238, n.1, p.1-18, 2006.

DORNELES, L. P. P.; WAECHTER, J. L.

Fitossociologia do componente arbóreo na floresta turfosa do Parque Nacional da Lagoa do Peixe, Rio Grande do Sul, Brasil. Acta

Botanica Brasílica, v.18, n.4, p.815-824, 2004.

DURIGAN, G. Métodos para análise da vegetação arbórea. In: CULLEN, L.; VALLADARES-PADUÁ, C.; RUDRAN, R. (Orgs.) Métodos de estudo em biologia da conservação e manejo da vida silvestre. Curitiba: Universidade Federal do Paraná; Fundação O Boticário de Proteção à Natureza, 2003. p.455-479.

FORMENTO, S.; SCHORN, L. A.; RAMOS, R. A. B. Dinâmica estrutural arbórea de uma Floresta Ombrófila Mista em Campo Belo do Sul, SC. Cerne, v.10, n.2, p.196-212, 2004.

GIBBS, P. E.; LEITÃO FILHO, H. F.; JABBOTT, R. $\mathrm{J}$. Application of the point-centred quarter method in a floristic survey of an area of gallery forest at Mogi-Guaçu, SP, Brazil. Revista Brasileira de Botânica, v.3, n.1, p.17-22, 1980.

GORENSTEIN, M. R.; BATISTA, J. L. F.; DURIGAN, G. Influência do padrão espacial sobre a estimativa de densidade arbórea do método de quadrantes: um estudo por meio de simulação de Monte Carlo. Acta Botanica Brasílica, v.21, n.4, p.957-965, 2007.

KOREZA, C.; DITTRICH, V.A. O.; SILVA, S. M. Fitossociologia do componente arbóreo de um fragmento de Floresta Ombrófila Mista Montana, Curitiba, PR, BR. Floresta, v.36, n.2, p.225-237, 2006.

MARTINS, F. R. Estrutura de uma floresta mesófila. Campinas: Universidade de Campinas, 1991. 246p.

MOREIRA, L. N.; MORENO, M. R.; REDLING, J. S. H. Estrutura populacional de Senefeldera multiflora em um trecho de borda na Mata Atlântica Estacional Semidecidual da Floresta Nacional de Pacotuba, Cachoeiro de Itapemirim, Espírito Santo. Revista Brasileira de Biociências, v.5, n.1, p.669-671, 2007.
MOSCOVICH, F. A.; BRENA, D. A.; LONGHI, S. J. Comparação de diferentes métodos de amostragem, de área fixa e variável, em uma floresta de Araucaria angustifolia. Ciência Florestal, v.9, n.1, p.173-191, 1999.

NARVÁEZ, I. S.; BRENA, D. A.; LONGHI, S. J. Estrutura de regeneração natural em Floresta Ombrófila Mista na Floresta Nacional de São Francisco de Paula, RS. Ciência Florestal, v.15, n.4, p.331-342, 2005.

NEGRELLE, R. A. B.; SILVA, F. C. Fitossociologia de um trecho de Floresta com Araucaria Angustifolia (Bert.) O. Ktze. No Município de Caçador - SC. Boletim Pesquisa Florestal, v.25, n.1, p.37-54, 1992.

OLIVEIRA, Y. M. M.; ROTTA, E. Levantamento da estrutura horizontal de uma mata de araucária no primeiro planalto paranaense. Boletim de Pesquisa Florestal, v.4, p.1-46, 1982.

RONDON NETO, R. M. et al. Análise florística e estrutural de um fragmento de Floresta Ombrófila Mista Montana, situado em Criúva, RS - Brasil. Ciência Florestal, v.12, n.1, p.29-37, 2002a.

RONDON NETO, R. M. et al. Caracterização florística e estrutural de um fragmento de Floresta Ombrófila Mista, em Curitiba, PR - Brasil.

Floresta, v.32, n.1, p.3-16, 2002 b.

RUSCHEL, A. R.; GUERRA, M. P.; NODARI, R. O. Estrutura e composição florística de dois fragmentos da floresta estacional decidual do Alto-Uruguai, SC. Ciência Florestal, v.19, p.225-236, 2009.

SCHAAF, L. B. et al. Modificações florísticoestruturais de um remanescente de Floresta Ombrófila Mista Montana no período entre 1979 e 2000. Ciência Florestal, v.16, n.3, p.271-291, 2006.

SILVA, A. F. et al. Composição florística e grupos ecológicos das espécies de um trecho de floresta Semidecídua Submontana da Fazenda São Geraldo, Viçosa-MG. Revista Árvore, v.27, n.3, p.311-319, 2003.

Revista Árvore, Viçosa-MG, v.34, n.3, p.513-520, 2010 
SILVA, F. C.; MARCONI, L. P. Fitossociologia de uma Floresta com Araucária em Colombo-PR. Boletim de Pesquisa Florestal, v.20, p.23-38, 1990.

SILVA, J. A. et al. Phytososiological survey in Brazil forest genetic reserve of Caçador. Plant Ecology, v.133, n.1, p.1-11, 1997.

SOARES, M. P. et al. Composição florística do estrato arbóreo de floresta Atlântica Interiorana em Araponga - Minas Gerais. Revista Árvore, v.30, n.5, p.859-870, 2006.
SONEGO, R. C.; BACKES, A.; SOUZA, A. F. Descrição da estrutura de uma floresta ombrófila mista, RS, Brasil, utilizando estimadores não-paramétricos de riqueza e rarefação de amostras. Acta Botanica Brasílica, v.21, n.4, p.945-957, 2007.

SPARKS, J. C.; MASTERS, R. E.; PAYTON, M. Comparative evaluation of accuracy and efficiency of six forest sampling methods. Proceedings of the Oklahoma Academy of Science, v.82, n.1, p.49-56, 2002. 